\title{
SCHOOLS AND TEMPLES AS EDUCATIONAL INSTITUTIONS OF NON-MUSLIMS IN ANATOLIA IN THE XIIIth CENTURY
}

\author{
Tunay KARAKÖK*
}

\begin{abstract}
In XIIIth century, after the Battle of Manzikert in 1071, Kutalmışoğlu Suleymanshah' leadership of the organization has been largely realized in Anatolia (Turkey) that a century Anatolian Seljuk Empire's domination continued. So much so that the first half of the century in question gives the image of Anatolia where a Seljuk rule was established, while the second half is an Anatolia where Turkish political unity and the authority of the Anatolian Seljuk State disappeared as a result of the Babais' Revolt in 1239 and the Kösedağ Wars in 1243, where confusion, chaos and instability prevailed. In this century, when the Anatolian Seljuk domination basically existed in small regional political structures known as the principalities in some places and which we see that they reached more than twenty large and small political structures, in Anatolia, besides Muslim subjects, there were also a considerable number of non-Muslim subjects and We see that Muslim Turks, who have been around two hundred years after their arrival, and these subjects live together. In addition to being in political structures, the educational activities of these subjects, who are seen to be in a religious, economic and socio-cultural fusion with Muslims, also take an important place in socio-cultural life. Here in this study; the institutions that have an important place in the education and training activities of Christian and Jewish subjects such as Greek and Armenian living in Anatolia in the XIIIth century are discussed. The subject of education, which is tried to be evaluated in terms of schools and mậbeds serving as schools, has been addressed by making use of the sources of the period and modern sources written in parallel with these sources.
\end{abstract}

Key Words: XIIIth Century, Anatolia, Non-muslim, Education

\section{YÜZYIL ANADOLU'DA GAYRIMMÜSLIMLERİN EĞİTIMM KURUMLARI OLARAK OKULLAR VE MÂBEDLER}

\begin{abstract}
Özet
XIII. yüzyıl; Anadolu coğrafyasında 1071 Manzikert Meydan Muharebesi sonrası İznik ve çevresinde Kutalmışoğlu Süleyman Şah önderliğinde kuruluş sürecini büyük oranda gerçekleştirmiş olan Anadolu (Türkiye) Selçuklu Devleti'nin hâkimiyet sürdürdügü bir asırdır. Öyle ki söz konusu asrın birinci yarısı tam bir Selçuklu hükümranlığının tesis olduğu Anadolu görüntüsü verirken, ikinci yarsı ise 1239 yılındaki Babailer
\end{abstract}

* Dr. Öğr. Üyesi, Bartın Üniversitesi Edebiyat Fakültesi Tarih Bölümü, tkarakok@bartin.edu. tr. ORCID: 0000-0003-4028-2148

(Makale Gönderim Tarihi: 13.04.2021-Makale Kabul Tarihi: 20.05.2021)

DOI: https://doi.org/10.53440/bad.915059 
İsyanı ve 1243 yılındaki Kösedağ Savaşları neticesinde Türk siyasi birliğinin ve Anadolu Selçuklu Devleti otoritesinin ortadan kalktığı, karışıklığın, kargaşanın ve istikrarsızlıkların hâkim olduğu bir Anadolu görüntüsü vermektedir. Temelde Anadolu Selçuklu hâkimiyetinin özelde ise yer yer beylikler adı ile bilinen ve irili ufaklı yirmiden fazla bir sayıya ulaşmış olduklarını gördügümüz bölgesel küçük siyasal yapılarında varlık gösterdiği bu yüzyılda Anadolu'da Müslüman tebaanın yanında Müslüman olmayan tebaanın da azımsanmayacak kadar sayıda olduğunu ve hali hazırda Anadolu'ya daha gelișlerinin üzerinden iki yüz yıl kadar bir süre geçmiş olan Müslüman Türkler ile bu tebaanın iç içe yaşadığını görmekteyiz. Siyasi yapıların içinde yer almalarının yanında dini, ekonomik ve sosyo-kültürel olarak ta Müslümanlar ile bir kaynaşma içine girdikleri görülen bu tebaanın eğitim öğretim faaliyetleri de sosyo-kültürel hayatın içerisinde önemli bir yer edinmektedir. İște bu çalışmada; XIII. yüzyıl Anadolu'da yaşayan Rum ve Ermeni gibi Hristiyan tebaa ile Yahudi tebaanın eğitim ve öğretim faaliyetlerinde önemli bir yer tutan eğitim kurumları ele alınmıştır. Okullar ve okul görevi gören mậbedler özelinde değerlendirilmeye çalışılan eğitim kurumları konusu, dönemin kaynakları ve bu kaynaklara paralel olarak yazılmış olan modern kaynaklardan da yararlanılmak sureti ile ele alınmıștır.

Anahtar Kelimeler: XIII. yüzyıl, Anadolu, Gayrimüslim, Eğitim

\section{Introduction: The Political Structure of the Anatolia in the XIIIth Century}

The XIIIth century was a period of many political turmoil in Anatolia. Between 1095 and 1270, the crusader attacks of the European Catholic Christians to take the Middle Eastern lands in the hands of the Muslims, upon various promises and demands of the Pope, affected Anatolia. In the XIIIth century, Babai revolts broke out in 1239 as a result of the unjust administration of Kaykhusraw II, the sultan of the Anatolian Seljuk state, against the Turkmen who migrated to Anatolia from Azerbaijan and Khorasan with the Mongol invasion.

With the victory of Manzikert, the gates of Anatolia were opened to Turkish-Islamic culture, but the Byzantine Empire and culture, which had been the baskın power in the Anatolian geography for many years, continued to resist this new culture and its representatives. Just as the political authority of Byzantium in Anatolia was destroyed with the victory in 1071; having been conquested by Muslim Turks, Anatolia had become an intense field of activity. Besides Turks, different elements such as Iran and Arabs had migrated to the region. In this respect, Anatolia had become a neighborhood where many national cultures met and interacted with each other. The native Christian Greeks, Armenians and Assyrians of Anatolia had to come face to face with the nations that were mostly Muslim and had to live together 
(Şeker, 1997: 49; Şeker, 2002: 66, 91). Undoubtedly, there were groups and groups belonging to various religions and sects in Anatolia in these centuries. However, in general, members of the religion of Islam and Christianity were at the forefront. The fusion of those who belonged to the two religions in question always favored Muslims and the Islamization of Anatolia took place in a short time (Turan, 2012: 46-49; Turan, 2002: 65; Yücel, 1995: 4144; Sevim-Mercil, 2004: 66-67; Agacanov, 2006: 91; Cahen, 2000: 59).

The Kösedağ War ith the Mongols in 1243 reversed the fortune of the Anatolian Seljuk State and three years later the Mongols set foot on the Anatolian lands. This was the beginning of a half century full of ravages, looting, throne fights among Seljuk princes and popular revolts. This period constitutes an important period of Anatolia in terms of Islamization as well as politically. As it is known, the Anatolian Seljuk State entered the Mongolian yoke, starting from around 1250. The first years were spent with throne fights between the Seljuk princes, which seemed to work well for the Mongols. For this reason, sometimes the princes supported one, sometimes the other. But in the end, they had to take over themselves because of the turmoil that ensued; Thus, they established their own administrative mechanisms by appointing general governors to Anatolia from 1277. These events worried the Turkmen lords and tribes. Especially those who were on the Byzantine border started to act as if they were semi-detached with the advantages of staying away from the control of the Mongolian central administration in these lands, they conquered with their own efforts. Turkmen sultans such as Aydınids, Mentese, Hamidids, Sarukhanids, Karesids, Karamanids and Ottomans were trying to expand in their own regions against Byzantium whenever possible, while at the same time they made an effort to establish a solid social and cultural structure (Bedirhan, 2004: 95-97; Cahen, 2000: 119-121; Baykara, 2002: 351-353). Towards the end of the XIIIth century, Byzantine lands in Anatolia were now receding to the southern basin of the Marmara Sea. The political, military, economic and religious struggles that took place between the Anatolian Seljuk State, the Byzantine Empire and the Ilkhanid State, which was an effective power in the Anatolian geography in the aforementioned century, will not prevent a new political power from emerging and taking the lead in the struggle for domination at the end of the century. This new power, known as the Ottomans principality, became stronger in a short time with political and military successes and finally, by the XVIth century, it managed to dominate the entire Anatolian geography alone (Turan, 2012: 97, 104, 116; Yücel, 1995; 66-69; Cahen, 2000: 74-75; Zeydan, 2012: 52; El Cez- 
vi, 2011: 69; Metin, 2012: 93; Kara, 2006: 109-116; Gordlevski, 1988: 72-74;

\section{Non-Muslims Of Anatolia In The XIIIth Century}

Before the Manzikert victory, while the Christian people were dominant in Anatolia, the sources grouped them as Greeks, Armenians and Assyrians, and the Jews stood like the parts of this dominant structure. After Manzikert, it is seen that Anatolia's Turkification and Islamization took place until the XIIIth century with the Muslim-Turkish element emigrating from Central Asia, Iran and other Islamic countries. Despite this, the Christian and Jewish people continued their existence in the minority status. Before Manzikert, the people in Anatolia were Christians. Christianity is among the religions that have the most believers in the world and subsequently decayed. The founder, İsa who Jews gave the title of Christ, the Greeks Christ, and those who believed in him Christiens, which means consecrated (Ocak, 1983: 6263; Houtin, 1984: 439).

Before the Anatolian Seljuk conquests, peoples of different religions, religions and sects lived in Anatolia. Of these, the Greeks were the leading people of the Anatolian people in terms of population and influence. Armenians were especially deployed in the Eastern Anatolia region where the Seljuks started their Anatolian conquests. Syriacs and relatively few Jews were also in Anatolia. In other words, when we look at the table, the peoples of the XIIIth century Anatolia are considered in three different groups with names such as Christians, Greeks, Armenians, and Assyrians, and finally they appear as Jews (Kemaloğlu, 2012: 171-172; Aktaş, 1996: 424).

First of all, if we look at the Christians from the peoples of the period, the first group we come across is the Greeks. Franz Babinger stated that the word "Greek" was an expression indicating the Roman and Byzantine Empires, sometimes used for "Roman state" and sometimes "Byzantine". Tuncer Baykara, in one of his works, stated that the Turks described those living in the west of the former inhabitants of Anatolia as Greeks and those living in the east of Anatolia as Armenian. What we mean here by the word "Greek" will be the Byzantine people, who live in the Anatolian lands of Byzantium and are almost all Orthodox (Babinger, 1993: 766; Baykara, 1997: 60; Baily, 2006: 41-59). Greeks, before the Seljuk Conquests, were the most crowded and it was the wealthiest, most educated and therefore the most active non-Muslim nation (Benjamin-Petachia, 2001: 42). It is known that the Greeks, who gave their names to Anatolia and formed the most crowded part of the population before the Turks, have lived in Anatolia since the ear- 
liest ages, continued their existence in time, and adopted this religion with the advent of Christianity. However, as these peoples accepted different sects of Christianity, some were called Greeks and some were called Armenians (Umar, 1988: 181; Baykara, 2004: 235). During the Seljuk period, the population in the cities was composed of Muslim Turks, Greeks and Armenians. However, the Greeks and Armenians, who were regarded as townspeople, constituted almost half of the city's inhabitants with the best estimate. Regardless of the Greek Pontus State in the Eastern Black Sea Region, the small Kingdom of Armenia in Çukurova and the Thrace regions, after the Seljuk conquests, $90 \%$ of the Anatolian population was Turks and the remaining $10 \%$ consisted of other non-Muslim elements, mostly Greeks and Armenians. During the period from the entry of the Turks to Anatolia to the end of the Turkish National Struggle, the Greeks, including the principalities, protected their religious and national identity under the roof of the Turkish states. They were not recruited like other non-Muslim communities. They were treated differently only in terms of taxes, and because of their trade, they represented the wealthy in general and lived a prosperous life (Rice, 1961: 49, 66, 78, 115; Akdağ, 1974: 14; Baykara, 2004: 235; Kafalı, 1997: 14-15; Barkan, 1952: 285).

Looking at the Armenians, another non-Muslim people of Anatolia of the period; The places that Armenians regard as "homeland" in the Eastern Anatolia region remained under Roman, Persian, Byzantine, Seljuk and finally Ottoman sovereignty, especially since they are located on the invasion routes reaching Anatolia. Armenians, who are among the inhabitants of Eastern Anatolia, have a long and troubled history. Non-Orthodox Gregorians separated from Greeks.They formed the Armenian nation. As an ethnic community, Armenians had adopted Christianity in the early fourth century. In the country where the Armenians lived, an Armenian priest named Kirkor Lusavoriç founded the first Christian church and Christianity started to spread in this region for the first time under his leadership. For this reason, those affiliated with this church were called Gregorian. The religious beliefs and rituals of the Gregorians differed significantly from Orthodox and Catholics. Since the Armenian Gregorian Church was a Monophysite, it was declared a heretic by the Catholic and Orthodox churches. Although Orthodox Byzantines made many attempts to establish religious unity with Gregorian Armenians, they were not successful (Rice, 1961: 69). Especially starting from the middle of the 11th century, after eliminating the Armenian political establishment in Eastern Anatolia, which attempted many bloody rebellions, 
it forced them to deport. As a result of these attempts, the conflicts between the Byzantine official authority and the Armenians increased and the Byzantines abolished the Armenian Kingdoms and Principalities in the east and dispersed their people by deporting them to different parts of the empire lands in the Balkans and Anatolia (İzgi, 2002: 6-7; Soykan, 1999: 210; Sevim, 1983: 13; Küçük, 1996: 557). Before the Seljuks, the Armenians were in the form of small political associations, known as the kingdom, under the rule of two large family branches (Bagratuni and Ardzruni), in the Eastern-Black Sea coasts, Georgia and Armenia, and the Van lake basin named Vaspurakan, subject to the Byzantine Empire. When the Seljuks started their conquests in Anatolia, the Armenians started to migrate to the south. After the Turks settled in Central Anatolia and then moved westward, Byzantium's contact with these regions was cut off. Philaretos, the Byzantine general of Armenian origin, who was previously assigned to defend the Malatya- Antakya line by the Byzantines against the Turks, took advantage of the turmoil and dominated the Armenians who remained loyal to Byzantium. He settled his son Barsam in Urfa, as he settled in Antakya by massacring the Greeks. Recognizing the sovereignty of the Great Seljuk ruler Malik-Shah I, Phileretos was able to maintain his rule over the Armenians until 1085 by paying taxes to Suleyman Shah and the Syrian Seljuk ruler Tutush. When Suleyman Shah, who captured Tarsus and Adana in 1082 and 1083, conquered Antakya in 1085, Philaretos fled with his son Barsam in Urfa. However, since he was not accepted by his son, he became a Muslim and settled in Marash. The Armenian principality founded by Philaretos came to an end. The continuous regression of Byzantium against the Seljuk moves made it possible for the regions where Armenians lived to pass easily to the Turks. As a result of the Turkish conquests, the Cilicia plain, Marash, Tarsus, Aintab, Edessa region were isolated from Byzantium, and the region was left to the Armenians. Armenians established small principalities here (Sevim, 1983: 41; Merçil, 2005: 73-74; Kafesoğlu, 1983: 69). Despite Turkish domination with the Seljuks, Erzincan remained as a large Armenian city. The Armenians almost showed loyalty to the sultans and thought that they were treated well, and only mourned for their deceased king. Because of their loyalty, Armenians were described as "millet-i sâdıka" in the sense of "loyal nation" in Ottoman history. However, they were also affected by the nationalism movement that spread to the world with the French Revolution during the First World War and they rebelled by taking advantage of the support of the imperialist powers in line with their own interests (Topçuoğlu, 2010: 589-597; Vryonis, 1971: 238). 
Another period is the Anatolian people, the Assyrians. The population of Syriacs in the world was around 3-4 million in the early 1990s. About 50,000 of them live in Mardin and Istanbul. There are active monasteries and churches. For centuries, the Syriac Church has been regarded as a "heretic" or "perverted" Christian sect by the Catholic and Orthodox Churches. Until the arrival of Islam in the region, they were subjected to great prosecution. Syriacs are actually members of the Antakya Church, which was established in the early days of Christianity (Çelik, 1987: 13). During the first conquest period of the Seljuks, Syriacs and Armenians constituted the majority of the population in Malatya and Edessa cities. During the Syrian campaign of Alparslan, there were 20,000 Syriacs and 8,000 Armenians in Edessa. XIII. Even at the beginning of the century, the Syriac and Armenian population in these cities were still in majority. Barsuma monastery, which was located around Malatya during the Anatolian Seljuks period, was an important religious center of the Syrians, gradually weakened, after the penetration of Islam into the regions dominated by the Assyrian Church, it lost its supporters and became today. Although the term Syriac belongs to various races, today it is used as the name of the supporters of a Christian sect and church (Çelik, 1987: 1, 2, 44, 71; Urfalı Mateos, 2000: 98; Turan, 1980: 75).

Within the scope of this study, the Jews as the last non-Muslim community of Anatolia were considered. Jews are also found in a small minority in Anatolia in the XIIIth century. After the Roman Emperor Titus took Jerusalem in $70 \mathrm{AD}$, he subjected the Jews to massacre. Jews who escaped from this prosecution migrated to Anatolia, where they continued their religious and cultural structures. It is known that there was a small Jewish community in the inner parts of Anatolia during the Byzantine period. The Jews living in Antalya continued their residence here after the conquest of the city by the Seljuks. Information about the Jews in the Seljuk period is mostly included in Eflâki's work. Eflâki mentions that during the Mawlana period there was a Jewish neighborhood in Konya and a rabbi drinking wine here. It is known that there were Jews among the Seljuk Turks and even one of the Seljuk Sultans of Konya was a Jewish vizier. Most of the Jews in the Seljuk country came from outside, seeing the commercial development in the XIIIth century. Like the Armenians and Assyrians, they were generally satisfied with living under the Turkish rule. Since they had a valid profession like a doctor or a money chancellor at that time, starting from the Seljuk palaces, they were treated with respect by the rulers and in the big cities. A Jewish traveler named Benjamin from Tudela, who traveled around Anatolia in the XIIIth century, saw 
the Jews as "allies of the Turks". A Jewish writer who Avram Galanti, Jews, Seljuks and later Turks talking about the situation in the administration of the Jews in Turkey as they always lived comfortably, the country that get along well with the people and the government has mentioned that the protection of the vault to which they comply with state laws (Barudel, 1994: 185, 191192; Eflaki, 1959: 213; Cahen, 2000: 213; İbn Batuta, 2007: 219; Tudela'lı Benjamin \& Ratisbon'lu Petachia, 2001: 79; Galanti, 1947: 8; Aksarayi, 2000: 124).

\section{Schools And Temples As Educational Institutıons Of Non-Muslıms In Anatolia In The XIIIth Century}

Schools and temples, a topic that gained importance in the educational activities of non-Muslims living in Anatolia in the XIIIth century, are actually considered as a pending title, which is generally included in the socio-cultural activities of the societies, and mostly because there is not much information in the sources. However, the period in Anatolia is a subject of education that has an important place in the socio-cultural relations of non-Muslim subjects and Muslim subjects. When approached from this framework, the subject of non-Muslims' educational institutions turns into an important topic (Vryonis, 1971: 239, 241).

Anatolia has been under the cultural influence of the religion of Islam since the Umayyad period. However, the majority of the indigenous people were Christians. After the Turks conquered Anatolia, an intense cultural interaction took place between Muslim and non-Muslim groups. These relations have continuously improved in favor of Muslims. As it is known, Islam expresses a positive opinion for the prophets of both Judaism and Christianity religions. For, all divine religions and prophets are venerable by Muslims. In fact, belief in the prophet is one of the basic principles of the religion of Islam. In XIIIth century Anatolia, religious communities that belong to three religions (Christianity, Judaism, Islam) are found. These communities are mostly Muslims, less Christians than them, and Jews as a small minority community by population density. Muslims; Christians in mosques, madrasahs, lodges, lodges and scientific assemblies; In churches and monasteries, Jews continued their religious lives in synagogues and synagogues. Educational institutions and educational activities of non-Muslim communities living in major Anatolian cities such as Ahlat, Erzurum, Sivas, Konya, Malatya, Erzincan and Harput are also important in terms of their application forms and scope (Vryonis, 1971: 254-255). 
Education is always an important issue in all religions. For, it is an important event to include educated people and the society in these activities, even if they are literate, in order to understand the orders and prohibitions of that religion thoroughly and to read and comprehend the holy book. At this point, the same was true for non-Muslim subjects in 13th century Anatolia. When we look at this really in action; Churches and monasteries appear as educational institutions of non-Muslim subjects in Anatolia of the period. They did not have madrasah type high schools like Muslims. Unfortunately, it is very difficult to find too many resources on these issues. However the number one educational institution for the Christian subject is churches and monasteries. Awḥad-al-dīn Kermānī who visited these monasteries in Anatolia during the period; In their relations in Mardin and Diyarbakır, those who are economically strong are admitted to the church, the poor are not admitted, a priest in the church in Diyarbakır guides the people, and mentions the acceptance of Islam as a result of his theological discussions shows that education and training are carried out in churches and monasteries (Akdağ, 1974: 99, 101, 110, 126, 432-433; Anonim, 1969: 121; Eflaki, 1959: 284; Turan, 1988: 43). In addition, by going to White Monastery (Aya Khariton), which is located near Konya, Mawlana, the religious and cultural information exchange of priests from various regions of the country sheds light on the issue. When we look at it, the educational institutions that we see that educational activities are not carried out within the framework of a curriculum or program, the non-Muslim schools that draw the picture, which serve as churches and monasteries, have played an important role for the non-Muslim subjects in Anatolia (Eflaki, 1959: 284-285; Cahen, 2000: 97-103; Tuncer, 2017: 75-79).

As can be understood from all this information, as it is included in the sources, information about the educational institutions of the Christian elements is more frequently encountered in this period, while the Jews, which are generally a closed community, can only go beyond saying that they fulfill their needs in synagogues or in ruins. When we start to examine the subject in more detail, religious places are the first places for educational activities for all non-Muslim communities. These places, which we know as a kind of temple, are not only places where religious activities are performed, but also places where educational activities are performed. Among the non-Muslim elements living in Anatolia during this period, the Greeks were orthodox, the Armenians were Gregorian, Catholic and Protestant, but the Assyrians belonged to the Nasturi sect. Jews, on the other hand, were drawing the image of a closed congregation. 
The oldest Christian temples of Anatolia were around Cappadocia. The Turks did not touch these structures in the form of churches or monasteries carved into the rocks after 1071 Manzikert. According to the records of the Armenian Gregorian church, there were bishops in Kayseri, Malatya, Sivas, Niksar, Göksun, Elbistan and Tzamandos in Anatolia in this century. These psychopaths also asked for help or support from the Anatolian Seljuk State from time to time. Erzincan and Erzurum were important Armenian cities in this context. Sis (Kozan) Van (Akdamar) and Eçmiyazin were the most important patriarchate centers. In this context, the shrines of the Armenian communities were mostly on the southeastern Anatolian borders (Cahen, 2000: 208, 211; Küçük, 1983: 736-137; Turan, 1980: 231-232). Barsuma Monastery, which was the patriarchal center of Assyrians among the Christian, nasturi and monophysite religious communities of Arab origin, was an important cultural center with its large religious staff and rich foundations. In addition, Antakya, Kayseri, Elbistan and Mardin Deyr ez Zor churches and monasteries were also important religious centers of this community. At the same time, these places, which are both a temple and an educational home, perform important functions in the name of education in Anatolia for Christian subjects. Konya, Sivas, Kayseri, Aksaray, Ankara, Amasya, Kastamonu, Denizli, Antalya, and Canik were among the other places where there were temples and educational institutions for the Christian population. According to Ak Manastır and Eflaki located in Konya-Sille, together with the Greek and Armenian churches located in the south of Konya Alaaddin Hill, a Jewish synagogue located in Konya and the rabbi assigned to this synagogue contributed to the educational activities of non-Muslim communities in the Anatolian period (Cahen, 2000: 206, 211-213; Konyalı, 1964: 1078, 1083; Eflaki, 1959: 463).

Acting on the foresights of the religion they believed in, Muslims tried to extend the period and areas of rule by making them loyal to the state rather than persecuting the non-Muslim subjects who were the inhabitants of the lands they dominated in XIIIth century Anatolia. The non-Muslims of the period who were left to their own in education and training activities as in all areas of life; While carrying out these activities in their shrines, over time, they reached a level that they can also take part in state positions. In these times, when we see that the children of charity, who were raised as Muslims in a system we call Devshirme, were able to take part in civil or military positions at the state levels; Nevertheless, we should not ignore the importance of temples or educational institutions they call schools for non-Muslims. 
Churches, monasteries and synagogues, which continued their activities with an understanding based on religious education, even though they were not planned and scheduled, served as important educational institutions for the Anatolian period. These places, which continue their activities with an understanding aiming to be a good Christian or Jewish, also appear as places where basic religious knowledge, basic mathematics knowledge, basic health and knowledge to be used in daily life are taught. The shrines, which are known as priests, priests, rabbis or Virgo, but ultimately carry out educational activities through people who are clergymen, are known as institutions that carry out educational activities in Anatolia until the establishment of schools in a modern sense.

\section{Conclusion}

Regardless of the rate of the Turkish population in Anatolia, it is a fact that there are not many Muslims everywhere. We sometimes see that political or religious reasons lead to the development of relations between the dominant Turks and the Christian church under their patronage. Non-Greek Christians were generally very pleased with their situation under the rule of the Turks, because they were now freed from the pressure of the Byzantine Church. Since the differences between the various sects of Christians did not concern the Seljuks, they did not tend to favor one sect over another. The sultans, whose tolerance was spoken of with great praise, were the ones who served the purposes of Islam the most: On the one hand, they gave Christians the opportunity to manifest their beliefs in their own cities as they wish, on the other hand they formed exemplary Muslim cities. They realized that cultural dominance was just as important as political domination. As a result, non-Muslims enjoyed the rights granted to them by Islamic law during the Seljuk period, which was the dominant power in Anatolia. They settled some of their legal issues through their own communities and also fulfilled their duties against the state.

In XIIIth century Anatolia there was a social structure consisting of nations belonging to various religions, languages, races and cultures. Looking at the Seljuks who were the rulers of the period and the principalities, the dominant element was the Turkish nation, and the non-Muslim elements that continued to live under the rule of the dominant elements were governed within the framework of certain legal statuses. In other fields, in accordance with the privileges given to them and their socio-economic status, they have established their schools in education and training activities besides their 
own institutions, and continued their education in their own language and outside the state control, depending on their religious and cultural organizations. As it is known, education and training is one of the most important indicators of the socioeconomic situation. Non-Muslims have become a qualified element with the opportunities provided by the state in terms of education, have kept their own culture alive and have become conscious of their independence. Dominant elements accepted education for non-Muslims as part of religious and sect privileges. Non-Muslim nations established and operated their schools through their own congregational organizations, just as they managed their temples themselves. In addition to churches which are schools and local communities in the first level of education for people, synagogues and similar temples, each congregation had a school connected to them. Secondary schools and teacher training schools were administered by the nation organizations. Each church served as a true educational guard under the supervision and supervision of its spiritual chiefs. The schools administered by non-Muslim nations were completely independent. Non-Muslims were able to teach in local languages in these community schools and arrange their curriculums as they wished. The state had never inspected these schools or did not require them to be inspected before. Non-Muslims were given the opportunity to act in an autonomous status in the field of education as well as in the field of religion and sect. Over time, community schools have become institutions where non-Muslims are taught their own history and culture, instilled in their ideas of independence, and even caused foreign states' politics for the sake of their national independence. 


\section{References}

AKDAĞ, Mustafa, Türkiye’nin İktisadi ve İçtimai Tarihi, I, İstanbul 1974.

AKSARAYÎ, Kerîmüddin Mahmud, Müsameretü'l-Ahbâr ve Müsayeretü'l-Ahyâr, Nşr. Osman Turan, Çev. Mürsel Öztürk, Ankara 2000,

AKTAŞ, A., "Anadolu Selçukluları Dönemi Hoşgörü Ortamında Müslüman-Gayr-i

Müslim İlişkileri”, Erdem, C. 8, Sayı: 23/II, Ankara 1996, s. 423.

ANONIM (), Menakıb-ı Evhadüddîn-i Kirmanî, Yay. B. Furuzanfer, Tahran 1969.

BABİNGER, Franz, "Rum”, İA, IX, MEB Yay., İstanbul 1993, s. 766.

BAİLY, A., Bizans Tarihi II, Çev. Haluk Şaman, İstanbul 2006.

BARKAN, Ö. L., "İstila Devirlerinin Kolonizatör Türk Dervişleri ve Zâviyeler”, Vakıflar Dergisi, Sayı: II, s. 279-304, Ankara 1952.

BAYKARA, Tuncer, I. Glyaseddin Keyhüsrev (1164 - 1211), TTK Yay., Ankara 1997.

BAYKARA, Tuncer, "Türkiye Selçuklu Döneminde Toplum ve Ekonomi”, Türkler, VII. Yeni Türkiye Yayınları, 323-378, Ankara 2002.

BAYKARA, Tuncer, Türkiye Selçuklularının Sosyal ve Ekonomik Tarihi, İstanbul 2004.

BEDIRHAN, Yaşar, Atçeken, Zeki, Selçuklu Müesseseleri ve Medeniyet Tarihi, Eğitim Kitapevi, Konya 2004.

BRAUDEL, Fernand Braudel, II. Felipe Döneminde Akdeniz, II, Çev: Mehmet Ali Kılıçbay, Ankara 1994.

CAHEN, Claude, Osmanlılardan Önce Anadolu, Çev: Erol Üyepazarı, İstanbul 2000.

ÇELIK, Mehmet. Süryani Kilisesi Tarihi. İstanbul 1987.

EFLÂKİ, Şemseddin Ahmed el-Ârifî, Menâkıbu'l Ârifin, Nşr. Tahsin Yazıcı, Ankara 1959.

GALANTİ, Galanti, Yahudiler ve Türkler, İstanbul 1947.

GORDLEVSKİ, Anadolu Selçuklu Devleti, Çev: Azer Yaran, Ankara 1988.

GRIGOREVIÇ, Sergey, Agacanov, Selçuklular, Çev: Ejber N. Necef, Ahmet R. Annabediryev, İstanbul 2006.

HOUTiN, Albert, "Hıristiyanlığın Kısa Tarihi", Çev. A. Küçük, Ankara Üniv. Illahiyat Fak. Dergisi, XXV, Ankara 1984, s. 437-455.

https://www.guncelkaynak.com/nedir/beylikler-donemi/, a.d. 05.02 .2021

İBN BATTUTA, Ebû Abdullah Muhammed bin Abdullah el-Levati et-Tancî , Büyük Dünya Seyahatnamesi, (Tuhfetû'n-Nûzzâr fî Garâibi'l-Emsar ve'l-Acâibi'l-Esfar), Haz. Ali Murat Güven, İstanbul 2007.

IZGİ, Ömer, “Türkler ve Ermeniler: Osmanlı Deneyimi”, Osmanlı'nın Son Döneminde Ermeniler, Kültür, Sanat ve Yayın Kurulu Yay., Ankara 2002.

KAFALI, Mustafa, Anadolu'nun Fethi ve Türkleșmesi, Ankara 1997.

KAFESOĞLU, İbrahim, Kafesoğlu, Sultan Melikşah Devrinde Büyük Selçuklu İmparatorluğu, İstanbul 1953.

KARA, Seyfullah, Selçukluların Dini Serüveni Türkiye'nin Dini Yapısının Tarihsel Arka Planı, İstanbul 2006.

KEMALOĞLU, Muhammed, "Türkiye Selçuklularında Gayr-ı Müslim Tebaa ile Kurulan Sosyal İlişkiler", Mehmet Akif Ersoy Üniv. Sosyal Bilimler Dergisi, 4, 7, (2012), s. 168-185.

KONYALI, İ. Hakkı, Konya Tarihi, Konya 1964. 
KÜÇÜK, A., “Türklerin Anadolu'da Azınlıklara Hoşgörüsü”, Erdem, C. 8, 23/II, Ankara 1996, s. 557.

KÜÇÜK, Abdurrahman, "Ermeni Katoğikosluğu ve Ermeni Meselesine Dair Bir Arşiv. Vesikası Üzerine”, AÜIFD, XXVI, Ankara 1983, s. 736-737.

MERÇİL, Erdoğan, Büyük Selçuklu Devleti, İstanbul 2005.

METİN, Tülay, Selçuklu El kitabı "Selçuklular Çağında Şehir Hayatı", Ankara 2012, s. 509-542.

OCAK, Ahmet Yaşar, Bektaşi Menậkıbnậmelerinde İslam Öncesi Inanç Motifleri, İstanbul 1983.

RİCE, T. T., Ancient Peoples and Places The Seljuks in Asia Minor, Thames and Hudson, London 1961.

SEVIM, Ali, Genel Çizgileri ile Selçuklu - Ermeni İlişkileri, TTK Yay., Ankara 1983.

SEVİM, Ali, Merçil, Erdoğan, Selçuklu Devletleri Tarihi Siyaset, Teşkilat ve Kültür, TTK Yay., Ankara 2004.

SIBT İBNU“L-CEZVİ, Mir'âtü'z-zamân Fi Târîhi'l-Âyân'da Selçuklular, Çev: Ali Sevim, TTK Yay., Ankara 2011.

SOYKAN, Tankut, Osmanlı İmparatorluğu'nda Gayr-i Müslimler, Ütopya Kitapevi, İstanbul 1999.

ŞEKER, M., Fetihlerle Anadolu'nun Türkleşmesi ve Íslamlaşması, Ankara 1997.

ŞEKER, M., Anadolu'da Bir Arada Yaşama Tecrübesi, Diyanet İșleri Başkanlığı, Ankara 2002.

TOPÇUOĞLU, A. A., "Gayrimüslimlerle Sosyal İlişkiler Hakkında İslâm Hukuku Açısından Bazı Mülahazalar", Uluslararası Sosyal Araştırmalar Dergisi, The Journal of International Social Research, 3/10, (2010), s.584-596.

TUDELA'LI BENJAMIN \& Ratisbon'lu Petachia, Orta Çăgda Íki Yahudi Seyyahın Avrupa, Asya ve Afrika Gözlemleri, Yay. Nuh Aslantaş, İstanbul 2001.

TUNCER, Ömer, 13. Yüzyıl Anadolu Devrimi: Sosyal Sınıflar, Kültürler ve Osmanlı'da Karşıdevrim Süreci, İstanbul 2017.

TURAN, Osman, Doğu Anadolu Türk Devletleri Tarihi, İstanbul 1980.

TURAN, Osman, Selçuklular Hakkında Resmi Vesikalara, Ankara 1988.

TURAN, Osman, Selçuklular Tarihi ve Türk-İslam Medeniyeti, İstanbul 2012.

TURAN, Refik, "Türkiye Selçukluları ve Anadolu Beyliklerinde Teşkilat", Türkler, 7, Yeni Türkiye Yayınları, 2002, s. 151-168.

UMAR, Bilge, Türkiye Halkının Ortaçağ Tarihi, İstanbul 1988.

URFALI MATEOS, Urfalı Mateos Vekayi-nâmesi (952 - 1136) ve Papaz Grigor'un Zeyli (1136 - 1162), Çev. Hrant D. Andreasyan, TTK Yay., Ankara 2000.

VRYONIS, Jr. S., The Decline of Medieval Hellenism in Asia Minor and the Process of Islamization From the Eleventh Through the Fifteenth Century, Los Angeles 1971.

YÜCEL, Yaşar, Türkiye Tarihi Fetretten Osmanlıya Kadar (1018-1030), I, TTK Yay., Ankara 1995.

ZEYDAN, Corci, İslam Uygarlıkları Tarihi, I, İstanbul 2012. 